\title{
Kilka myśli o teologii dla przyszlych studentów
}

Teologia niegdyś nosiła miano królowej nauk i żaden uniwersytet nie mógł powstać bez wydziału teologicznego. W XVIII wieku świat nauki został jednak zdominowany przez utylitaryzm i empiryzm, a w konsekwencji na czoło wysunęły się nauki przyrodnicze. Wiedzą miało odtąd być tylko to, co sprawdzalne, mierzalne i praktyczne, zaś celem badań naukowych miał być postęp cywilizacyjny. Kościół katolicki, przeżywający problemy wewnętrzne (np. jansenizm, kasaty zakonów) z różnych powodów nie mógł w porę zareagować, aby dostosować formy uprawiania teologii do tych nowych wyzwań, skutkiem czego drogi nauk przyrodniczych i teologii rozeszły się na długie dziesiątki lat. Dopiero w latach 80 . XIX wieku nastąpił renesans nauk teologicznych i oparcie ich na sprawdzonym, całościowym i uniwersalistycznym systemie św. Tomasza z Akwinu. Rozpoczął się wtedy żmudny proces odbudowywania statusu naukowego teologii i jej pozycji wśród dziedzin nauki, kontynuowany w zasadzie do tej pory, chociaż utrwalone schematy myślenia $\mathrm{w}$ nauce są bardzo trudne do przełamania i status teologii jako nauki jest trudny do odbudowania. Jest to oczywiście możliwe. Trzeba powiedzieć, że zwłaszcza powrót teologii na uniwersytety rokuje bardzo dobrze, byle teologowie mocniej zwrócili uwagę na obronę statusu naukowego teologii, czego brakuje.

$$
* * *
$$

W pełni zrozumiałe są dylematy i niepokoje osób zastanawiających się nad podjęciem studiów teologicznych i jednocześnie pozostania w świecie. Pytają one o znaczenie tego studiowania dla ich przyszłego życia, o możliwość podjęcia pracy itp. Chcę je uspokoić, że teologia jest pełnoprawną i odrębną dyscypliną naukową, podobnie jak filozofia lub prawo. Posiada swój przedmiot poznania i metodę postępowania badawczego. Błędne jest mniemanie, że wiedzą naukową nie może być to, co jest jednocześnie przedmiotem wiary, gdyż np. stanowisko, że Bóg nie istnieje, nie opiera się na dowodach empirycznych, lecz jest również w jakiś sposób sprawą wewnętrznego przekonania, indywidualnej decyzji człowieka. Papież Benedykt XVI podczas wykładu na Uniwersytecie w Ratyzbonie w 2006 roku, argumentując za naukowością teologii, wskazał trafnie, że nauka jako systematyczne i metodologiczne uzyskiwanie pewności prowadzonych badań nie może wykluczyć problemu Boga, a teologia w ścisłym 
sensie jest poszukiwaniem rozumnego uzasadnienia wiary, które dokonuje się na uniwersytecie $\mathrm{w}$ żywym dialogu z innymi naukami. Na pewne pytania, jakie stawia człowiek, może odpowiedzieć tylko teologia, np. skąd pochodzimy i dokąd zmierzamy?

$$
* * *
$$

Zależnie od indywidualnych zainteresowań studentów różne działy teologii czy też przedmioty dodatkowe i uzupełniające mogą dać im dużą satysfakcję poznawczą. Ktoś, kto lubi historię, nie będzie na pewno nudził się, poznając np. historię i geografię biblijną, dzieje myśli teologicznej ojców Kościoła, czyli patrologię lub historię Kościoła, ukazywaną przecież na tle historii powszechnej. Zainteresowani filozofią, etyką i logiką spotkają się $\mathrm{z}$ tą problematyką w ramach wielu wykładów, zwłaszcza na początku studiów, podejmując szeroko problematykę filozoficzną. Katolicką naukę społeczną, nauki o rodzinie, pracę socjalną, komunikację społeczną, psychologię i antropologię będą chętnie zgłębiali ci, których interesuje człowiek i życie społeczne. Wszystkich natomiast, jako wierzących, zaciekawią z pewnością szczegółowe zagadnienia z dziedziny teologii dogmatycznej, moralnej, duchowości, biblistyki, prawa kanonicznego czy ekumenizmu. Oczywiście, są też lektoraty języków obcych, w tym łaciny, tak ważnej dla zrozumienia kultury europejskiej. Nasi studenci mają do dyspozycji bibliotekę dobrze zaopatrzoną w literaturę nie tylko teologiczną, ale także z wielu innych dziedzin nauki. Przede wszystkim zaś studiowanie na naszej uczelni staramy się opierać na klasycznej relacji mistrz - uczeń, która optymalnie wykorzystuje wiedzę i osobowość nauczyciela oraz talenty i pracę studenta.

$$
* * *
$$

Współcześnie teologia to wiedza przeznaczona nie tylko dla osób duchownych. Studia teologiczne, podobnie jak w pewnej mierze także i filozoficzne, wyposażają każdego młodego człowieka w to, co najbardziej potrzebne w życiu. Pomagają bowiem szukać odpowiedzi na pytania o Boga, prawdę, miłość, sens i szczęście. Dają narzędzia do poszukiwania wolności i mądrości. Uczą umiejętności poprawnego, logicznego i krytycznego myślenia, a także rozwiązywania problemów i podejmowania decyzji. Wszystko to konieczne jest do wykonywania każdego zawodu, pełnienia każdej roli społecznej, i to na każdym etapie życia człowieka. Podstawą owocnego studiowania jakiejkolwiek dyscypliny są nie tylko nowoczesne sale wykładowe i pomoce dydaktyczne, ale kultura bycia, wytrwałość i ciągłość podejmowanego wysiłku, pracowitość wykładowców i studentów, a także zwykła uczciwość. Staramy się, aby takimi walorami charakteryzowały się studia w naszej uczelni. Podważanie naukowego i praktycznego charakteru teologii prawdopodobnie nie ustanie, toteż każdy teolog w punkcie wyjścia 
zgadza się na uprawianie nauki spotykającej się z niezrozumieniem. Wymaga to pewnej dozy odwagi, ale właśnie takie wyzwania często pociągają młodego człowieka, szukającego czegoś więcej od życia niż konsumpcji. Patrząc na sytuację współczesnego człowieka, chciałbym w tym kontekście sparafrazować myśl niemieckiego filozofa Roberta Spaemanna - teologia będzie istniała dopóty, dopóki będziemy chcieli stawiać granice naszemu uprzedmiotowieniu.

ks. Janusz Królikowski dziekan Wydziału Teologicznego Sekcja w Tarnowie 